\title{
IZBRANA POGLAVJA IZ ZGODOVINE SELITEV OD ZAČETKOV DO DANES
}

\author{
Matjaž Klemenčič, Aleš Maver: Izbrana poglavja \\ iz zgodovine selitev od začetkov do danes. Uni- \\ verzitetna založba Univerze, 274 str. Maribor, \\ 2017.
}

Spremenjeni značaj, smeri in spremljajoči procesi selitvenih tokov zadnjega desetletja so tematiko mednarodnih selitev močno popularizirali. Omenjeno delo pa ni te vrste: avtorja, zgodovinarja mariborske filozofske fakultete, se z mednarodnimi selitvami ukvarjata že dolgo. Ni dvoma, da je »motor« tega podjetja profesor Matjaž Klemenčič, avtor vsaj desetih obširnejših monografskih del s selitveno in širše etnično tematiko, geografski srenji znan tudi kot predavatelj na Oddelku za geografijo Filozofske fakultete Univerze v Ljubljani, mentor in član komisij. Raziskovalno težišče so zlasti čezmorske selitve Slovencev, torej kompleks »izseljenstva«. Raziskovanje je utemeljeno na skrbnih in obsežnih preučevanjih arhivskih gradiv. Najobsežnejša monografsko delo pa je trijezična trilogija o boju koroških Slovencev za svoj etnični obstoj, ki jo je pripravil skupaj s svojim (že pokojnim) očetom prof. dr. Vladimirjem Klemenčičem.

Pričujoče delo pa ni te vrste in iz izjemno bogatega opusa nekako izstopa po širini in smeri. V bistvu je pregledno delo, a veliko več kot zgledno urejen kompilat dinamike mednarodnih selitev. S stališča zgodovinske stroke je zanimiv sam pristop: predmet obravnave je sam proces selitev, ostalo so geografske, politične, kulturne in gospodarske okoliščine. Nad 270 strani obsežna monografija je razdeljena na dva dela: globalni del mednarodnih selitev ter selitve iz slovenskega kulturnega prostora. V obeh delih sta avtorja uporabila zaporedni kronološki pristop z obravnavo najprej starejših in nato vse mlajših obdobij, vse do danes. Prikaz je sistematičen in zajema oris selitvenega dogajanja na vseh celinah, kolikor je mogoče rekonstruirati vedenje o selitvah v starejših obdobjih zaradi dokaj skromnih podatkov. Pisni viri so za mnoge selitvene tokove najpogosteje le omembe v zapisih; kronisti pa niso bili vselej vzor natančnosti. Avtorja sta uporabila interpretativni pristop in oris naslonila na prikaz razmer in okoliščin, ki so selitve sprožale, omogočale, spodbujale in regulirale; motive je pač mogoče le okvirno oceniti. Pred bralcem je zelo uravnotežen prikaz selitvenega dogajanja v določenih časovnih obdobjih ter večjih zaključenih geografskih območjih. Novejša obdobja so prikazana natančneje in z mnogimi podatki. Avtorja se nista posebej spuščala v skoraj klasično klasifikacijo selitev v politične ali ekonomske; to opredelita kot prevladujoče okoliščine. Zgodovinski orisi omogočajo vpogled v vsakokratne družbene in politične razmere, v katerih so selitveni tokovi predstavljali pomemben, v nekaterih primerih pa tudi odločilen družbeni tok. To 
velja še posebej za ameriško celino, kjer je kolonizacija teh prostorov s strani evropskih kolonizatorjev (Angležev, Francozov, Špancev in Portugalcev) najprej reducirala domače prebivalstvo, ga potisnila v manj privlačne predele, sprožila nasilno uvažanje sužnjev iz Afrike in slednjič spodbudila enormne selitvene tokove iz Evrope. Šele pozneje so sledile selitve tudi z drugih celin in oblikovale današnjo družbeno strukturo, ki je večinoma utemeljena prav na prepletu raznolikih selitvenih tokov.

Drugi del monografije se posveča selitvam v slovenskem kulturnem prostoru. Avtorja sta se držala enakega pristopa kronološkega zaporedja, le da je potem regionalni prikaz zanemarljiv spričo relativno skromnih dimenzij slovenskega ozemlja. Večjo (pravzaprav največjo) težo sta namenila izseljevanju kot prevladujoči obliki selitvene dinamike. Zadnji del slovenske selitvene zgodbe opredeljuje Slovenijo kot deželo priseljevanja, kronološko pa sega od druge svetovne vojne dalje ter zaključuje $\mathrm{z}$ atipičnim poglavjem (primerjaje s celotno monografijo) - s položajem priseljencev v Sloveniji. Sledi še tabelarični dodatek, ki bralcu omogoča vpogled v maso in smeri selitvenih tokov, na koncu pa avtorja navajata številne vire.

V poplavi del s selitveno dinamiko, ki jo lahko razumemo kot interdisciplinarni odgovor na popularnost te tematike $\mathrm{v}$ sedanjem času in za katero moramo najprej ugotoviti precej nekritično sledenje ideološkim imperativom, je predstavljeno delo konceptualno sveža in v realizaciji dokaj dosledna analiza selitev kot oblike geografske distribucije človeške vrste. Homo migrans ima glagol »seliti se« očitno za svoj imperativ, neko konstanto, ki mu narekuje slediti inerciji radovednosti, želji po spoznavanju novega in vztrajnemu sledenju iskanja (boljših) priložnosti. Človek - kolonizator. Del naslova knjige (»od začetkov«) se bere na prvi pogled skoraj kot približek bajeslovnim pristopom (»od začetka časov«), avtorja pa prav neznano sivo liso našega védenja o domnevnih premikih homo sapiensa in njegovih predhodnikov postavljata na realna tla. Premiki so bili skoraj vedno kombinacija različnih motivov, okoliščine pa so bile pogosto zelo pomemben dejavnik. Selitve so realnost, njihova masa, smer in posledice pa okoliščine tega procesa. Delo je odličen priročnik za vsakogar, ki se želi nekoliko bolj poglobljeno lotiti tematike selitev. Da so to »izbrana poglavja« je morda bolj opozorilo bralcu, naj ne pričakuje navedb čisto vsega, po prebranem pa ostaja vtis zelo celovitega, kompleksnega, uravnoteženega prikaza migracij od nam kolikor toliko znane (dokumentirane) zgodovine do sedanjosti. Vrsta tabel, številčnih podatkov, omemb virov, preglednic med besedilom in v priloženem dodatku ter ličnih črno-belih kartografskih prikazov pa dopolnjujejo vtis odličnega dela in dobrega priročnika, še posebej tudi za geografsko strokovno rabo. 